\title{
Success at the farm-level in payments for ecosystem services: monetary incentives, participatory processes and institutional adaptation all matter
}

\author{
Authors \\ Geoff J. Wells ${ }^{1, *}$, Esteve Corbera ${ }^{2}$, Janet Fisher ${ }^{3}$, Casey Ryan ${ }^{3}$ \\ ${ }^{1}$ Stockholm Resilience Centre, Stockholm University \\ ${ }^{2}$ Institut de Ciencia I Technolgia Ambientales, Unversitat Autónoma de Barcelona \\ ${ }^{3}$ School of GeoSciences, University of Edinburgh \\ ${ }^{*}$ Corresponding author
}

Emails: geoff.wells@su.se, Esteve.Corbera@uab.cat, Janet.Fisher@ed.ac.uk, casey.ryan@ed.ac.uk

This is a non-peer reviewed preprint submitted to EarthArXiv and Elsevier. The authors are solely responsible for any errors or omissions in this version of the manuscript or any version derived from it.

\begin{abstract}
While payments for ecosystem services (PES) schemes are increasingly common, in most cases, their effectiveness has lagged behind initial expectations. A major debate exists around whether performance can be improved by prioritising project design features that align with the theoretical, economistic model of PES, or whether, where necessary, it is more important for projects to depart from this model to build local support and legitimacy. In this study we address this gap by examining how financial incentives, participation in decision making and organisational centralisation have supported land management outcomes across 39 smallholdings participating in carbon agroforestry PES schemes in Mexico and Mozambique. We use interviews, tree growth records and fuzzy set qualitative comparative analysis (QCA) to assess how these three design features, and contextual variables on household wealth and farm-level water availability, have related to the actual level of aboveground biomass (AGB) accumulated on each farm - the main land management objective in such schemes. We then use interviews with farmers and project staff to gain a more in depth understanding of how these design features are linked to land management outcomes. We find that, in our cases, both monetary incentives and good participation in decision making where integral to good outcomes. The level of (de)centralisation was unimportant as long it was perceived as legitimate locally, and accounted for existing social,
\end{abstract}


cultural and historical context. Our findings suggest that attempts to improve the performance of PES schemes by enshrining 'best practice' or key design principles must put equal emphasis on economistic design principles and the maintenance of local legitimacy, and should be flexible enough to allow for local processes of institutional bricolage. Given the typical nature of our cases, we argue that our findings provide new insights relevant to the wider PES field.

\section{Introduction}

While payments for ecosystem services (PES) schemes are increasingly common, in most cases, their effectiveness has lagged behind initial expectations (Börner et al., 2017). Many of the ongoing debates in PES focus on the causes of this underperformance, and which project design features are important for a successful scheme (Huber-Stearns et al., 2017).

One of these debates revolves around whether PES projects should prioritise project design features that align with the theoretical, economistic model of PES, or whether, where necessary, projects should depart from this model to build local support and legitimacy (Ezzine-de-Blas et al., 2016; Pascual et al., 2014; Shapiro-Garza et al., 2020; Wunder et al., 2018). At the project level, this can be seen in decisions about whether to prioritise the delivery of monetary incentives (e.g. through strict adherence to neoclassical economistic principles in conducting monitoring, sanctioning and payments), over other design features aimed at building local support (e.g. through more flexible and participatory decision making). Associated with this is an apparent tension between a desire to exert centralised organisational control within PES projects (e.g. through a greater role for administrators in targeting, monitoring and sanctioning), and a desire to make such schemes more decentralised 'community based' processes. Understanding how these three design features (monetary incentives, local participation in decision making and the degree of centralisation) relate to outcomes at the local (e.g. farm) level remains a research frontier.

In this study we examine how financial incentives, participation in decision making and organisational centralisation have supported land management outcomes across 39 smallholdings participating in carbon agroforestry PES schemes in Mexico and Mozambique. We use interviews, tree growth records and fuzzy set qualitative comparative analysis (QCA) to conduct a multiple comparative case study. We assess how these three design features, and contextual variables on household wealth and farm-level water availability, have related to the actual level of aboveground biomass (AGB) accumulated on each farm - the main land management objective in such schemes. We then use interviews with farmers and project staff to gain a more in depth understanding of how these design features are linked to land management outcomes. In doing so we draw on critical institutionalist theories to observe how project design features have evolved alongside their local context. Our research question is: in our cases, how have different perceptions of monetary incentives, local participation in decision making and organisational centralisation co-occurred with different AGB outcomes?

Below we first provide conceptual background, before presenting our study areas, methods and results. We conclude with a discussion of the implications of our findings for the PES field.

\section{Conceptual background}


Our study focuses on debates around three key design features of PES: incentives; participation in decision making; and the (de)centralisation of project processes. We consider these features alongside the socio-economic and environmental contextual variables of household wealth and water availability. In conducting the analysis we adopt a critical institutionalist perspective, where we examine the degree to which project processes were in fact 'designed', or whether they evolved organically alongside existing institutions, norms and the agency of individuals. Below we define each of these concepts and briefly review their links to PES theory.

\section{Monetary incentives and participation in decision making}

At the core of PES theory is the notion that monetary incentives cause predictable changes in behaviour (and so to land management outcomes) (Engel et al., 2008; P. J. Ferraro \& Kiss, 2002). Yet contributions from behavioural and ecological economics challenge this idea, and suggest that the extent to which a person responds to a financial incentive is moderated by their socio-economic context, and the presence of other non-monetary motivations (Bryan, 2013; Ezzine-de-Blas et al., 2019; Singh, 2015). Additionally, it is also argued that in some cases the introduction of a financial incentive can cause a perverse outcome by 'crowding out' existing non-monetary motivations for sustainable land management (Chervier et al., 2017; Kerr et al., 2012; Martin et al., 2014; Vatn, 2010).

Similarly, debates on the appropriate levels of participation in decision making within a scheme (a seperate concept to the willingness of landowners to join or 'participate in' PES, which is discussed in depth elsewhere; e.g. J. Fisher, 2012; Lansing, 2017) also reveal disagreements amongst PES theorists. Participatory decision making in PES has mainly been analysed in relation to 'procedural equity' (or similarly, 'procedural justice', or 'procedural fairness'), with many researchers arguing that schemes which include local participants in decision making are likely to have greater community and political support (or 'local legitimacy'), and so to be more successful (E. Corbera et al., 2007; Martin et al., 2014; Pascual et al., 2014). On the other hand, some view that a focus on such 'political' aspects may be presenting a barrier to what are argued to be other more important design principles, such as strict sanctioning of non-compliance (Wunder et al., 2018). In this study we examine how a series of local farmers have responded to incentives and participatory decision making, and how this is linked to actual land management outcomes on their farms (i.e. levels of AGB).

\section{Organisational (de)centralisation}

In addition to incentives and participation in decision making, we introduce a third concept examining the degree of organisational decentralisation in PES. The concept of 'organisational centralisation' differs in its scope from the broader concept of 'decentralised governance' in the wider natural resource management literature, but has many of the same justifications. Over the last three decades, notions of decentralised governance have become popular in natural resource management theory due to both normative views on the benefits of its apparent democratising power, and because of assumptions that it is more effective than centralised approaches (Larson \& Soto, 2008; Ribot \& Larson, 2004). In response, many researchers have highlighted that decentralisation does not necessarily solve issues related to elite capture, scale mismatches, and a lack of accountability (Blaikie, 
2006; Lockwood et al., 2010). Others thus advocate a co-governance compromise (or similarly, networked or nested governance) in which centralised and decentralised approaches are balanced to accommodate coordinated decision-making at different levels (Leach et al., 2007). In practice, decentralisation of governance involves transferring power to make NRM decisions from traditionally centralised institutions to lower levels (e.g. from national- to village-level government), with the aim of better grounding practices in local realities and of making interventions more responsive to community needs (Blomquist et al., 2010).

In contrast to the broader concept of decentralised governance, organisational decentralisation has similar justifications but is focused on decentralisation within an organisation or institution as opposed to between institutions. It has been utilised to examine the operation of organisations in the international development and public policy fields (Bainbridge, 2000; Fowler, 1992, 2000; Gibbs et al., 2000; Madon, 1999; Peckham et al., 2005), but, to our knowledge, has not been applied to PES. In PES discussions of decentralisation have been concerned with broader aspects of decentralised governance. Early advocates framed PES itself as a broad form of democratic decentralisation in a neoliberal sense: PES would allow better decisions about environmental resources through handing decisions to free and rational individuals in the marketplace, rather than being made by centralised governmental command-and-control structures (Engel et al., 2008). Following on from this, there have been further higher-level assessments of power dynamics between PES institutions at different levels (Esteve Corbera et al., 2009), vertical and horizontal coordination of activities between institutions (Kolinjivadi et al., 2014), the role of organisational leadership (Escobar et al., 2013), and the characterisation of PES schemes as a middle-ground hybrid type of governance that is neither purely market-based, nor a form of command-and-control (Muradian et al. 2012). While useful for understanding how PES interacts with the wider governance context, examinations of organisational decentralisation within a PES scheme are new.

While not addressed directly in the PES literature so far, organisational decentralisation provides a way to summarise many existing debates in PES. On the one hand, advocates of centralised approaches seek to exert control and minimise risks within a PES project through the robust implementation of centrally managed (e.g. project-wide) rules, land use designs and sanctioning (Ezzine-de-Blas et al., 2016; Paul J. Ferraro, 2001; Wunder et al., 2018). On the other hand, decentralised approaches emphasise more community-based structures that rely on cooperation and local flexibility (Esteve Corbera \& Brown, 2008; Nieratkaa et al., 2015; Pascual et al., 2014). Both sides argue that different degrees of (de)centralisation will improve land management outcomes. As for incentives and participation, in this study we assess how different types of centralisation have occurred alongside different land management outcomes in each of our cases. In line with existing literature that PES institutions are often hybrid processes (rather than adhering to a theoretical ideal type) (Muradian et al., 2010; Shapiro-Garza et al., 2020), we define separate variables for the degree of centralisation and decentralisation, rather than measuring them on a single continuum. A case can thus exhibit aspects of both centralisation (e.g. close administrative control) and decentralisation (e.g. farm-level flexibility). 
To contextualise each case, we include two concepts relating to the household and farm socio-economic and environmental contexts. Household wealth has been shown to be a key indicator of the ability of a household to effectively implement land management interventions in forest PES and similar schemes (Hayes et al., 2017; Lansing, 2017; Suich et al., 2015; Van Oosten, 2013). For environmental context, water availability is used as a key variable in the selection of species and expected growth rates in agroforestry and other types of forestry (Ashton \& Montagnini, 1999; Bontemps \& Bouriaud, 2013).

\section{Critical institutionalism in PES}

Throughout this study we adopt a critical institutionalist perspective. Institutionalism is a broad school of thought in social science which seeks to explain human behaviour through the influence of our surrounding political and social rules, practices, norms and structures (Lowndes \& Roberts, 2013). Within the institutionalist school there are many and varied perspectives which can be usefully categorised into 'mainstream' and 'critical' (also sometimes 'post-') institutionalism (Cleaver \& De Koning, 2015). Within NRM theory, mainstream institutional approaches have been defined as those which assume that one can identify and design optimal institutions to achieve a desired behavioural outcome (Cleaver, 2017; De Koning \& Benneker, 2012). Critical institutionalism, on the other hand, emphasises that institutions and their outcomes are rarely explicitly designed but instead evolve from existing social and historical processes, and the individual agency of participants. Associated with this perspective is the concept of institutional bricolage, where institutions are continually being evolved and remade from existing rules, norms and beliefs in order to find a socially acceptable way for an organisation or project to operate (De Koning \& Benneker, 2012).

Much of the current literature on PES design is implicitly mainstream institutionalist: it focuses on finding the necessary, desirable or optimal types of PES design, and in doing so implies a high level of administrative control over the shape of project institutions and processes (Bennett \& Gosnell, 2015; Börner et al., 2017; Engel et al., 2008; Grima et al., 2016; Huber-Stearns et al., 2017; Paudyal et al., 2018; Wunder et al., 2018). Alternatively, a small emergent literature argues that PES institutions usually emerge from local context and individual agency rather than being imposed (Shapiro-Garza et al., 2020; Van Hecken et al., 2015). By adopting a critical institutionalise perspective we align with this new literature and seek to assess why different organisational processes have emerged from the local context.

\section{Methods}

\section{Study areas}

We focus on the experiences of 39 farmers participating in two smallholder carbon agroforestry PES schemes: Scolel'te in the southern State of Chiapas in Mexico; and the Sofala Community Carbon Project in central Mozambique. The projects have been running since 1997 and 2007 respectively, and both occur in remote, rural areas dominated by subsistence agriculture and/or livestock systems (Hegde et al., 2015; Ruiz-De-Oña-Plaza et al., 2011), with high levels of poverty by global and national standards (OPHI, 2015, 2018). The schemes implement similar types of agroforestry using native species, with species and planting designs adapted to the local context. The farms examined in this study are usually one to two hectares in size, and are monitored for 10 years after initial tree planting. 
Both projects are funded by a mix of donor funds, and carbon credits generated under the Plan Vivo Carbon Certification system (Plan Vivo, 2013), and so have similar organisational processes and land management objectives that are typical of forest PES schemes. Farmers who opt to participate are coordinated and paid to plant and grow trees through a three-tier structure: 1) at the project-level, an in-country intermediary (a local non-government organisation) administers funding, high-level technical support, monitoring and farmer payments; 2) at the village-level, local coordinators and technicians organise farmers and provide extension services; and 3) at the farm-level, farmers design and implement their own tree planting plans. Within this common structure, the degree of participation in decision making, and the degree of centralisation, varies from village to village: some are very centralised and directed, while others are more dispersed and consultative. All farmers within a project receive the same payment per hectare subject to a minimum level of tree growth being achieved, while the efficiency (and perceived importance) of payment delivery varies between farmers.

We include in our study farmers from eight different villages (six from Mexico and two from Mozambique) with varying village structures. Broadly, Yaluma (YLM) in Mexico, and Nhambita (NMB) and Mutiabamba (MBB) in Mozambique have hierarchical village structures, Naha (NH) and Punta Brava (PB) in Mexico are moderately centralised, while Alan-Samariakantajal (ASK), Nuevo Rodulfo Figeuroa (NVR) and Villa las Rosas (VIR) are relatively decentralised. Further nuances of particular villages and farmers are further elaborated in the results section.

\section{Study design}

We conducted a multiple comparative case study analysis to explore qualitatively the broad proposition that the PES design features outlined above matter for land management outcomes (Yin, 2014). We chose a qualitative approach as the fieldwork was exploratory in nature and aimed at gaining rich, in depth accounts of PES project design at the farm level. We define each case (or unit of analysis) as the experience of each farmer in the project, and their associated level of AGB accumulation. Based on interviews with farmers and technicians, and on project records, we characterised the design features, socio-economic and environmental context, and level of AGB in each case. We then used QCA (described further below) to identify patterns across our cases, followed by analyses of farmer interviews. We used the farmer interviews to gain deeper understandings of how and why these design features affect, and differ, between different farmers. We contend that our study projects represent typical smallholder carbon agroforestry projects in rural developing countries. We use these similarities to highlight lessons for such projects more broadly.

\section{Data sources}

The main sources of data were semi-structured interviews with participating farmers. We selected farmers through a theoretical purposive sample (Guest, 2006), aimed at interviewing farmers in as many different villages as field logistics would allow, targeting farmers with different levels of AGB performance (as assessed from project records). We conducted interviews during fieldwork visits during 2017 and 2018. The interviews took the form of broad, semi-structured conversations about the respondent's experience throughout the project, covering aspects of incentives, participation and centralisation, as well as open 
questions on why some farmers have bigger or different trees compared to others. Interviews were conducted with prior informed consent, and anonymity was maintained throughout. We documented interviews in notes and audio recordings, sometimes with the assistance of translators fluent in the local languages. To assess the wealth of each household, in each village we also conducted with a group of village leaders a wealth ranking of all households participating in the project (Narayanasamy, 2009).

We also used project records for additional data on administrative arrangements and payments, and to model tree growth (see below). We used secondary data on annual rainfall to assess water availability (see below).

\section{Case characterisation}

For each of our cases we used the data to characterise the relative level of monetary incentives, participatory decision making, (de)centralisation, wealth, water availability and AGB. These are high level constructs that are difficult to measure and assess in practice. Thus, borrowing language from statistics, we framed these high-level concepts as 'latent' (i.e. hidden) constructs that can only be assessed through more attainable 'observed' (i.e. proxy) variables. The observed variables and their sources for each latent construct are summarised in Table 1 (see Supplementary Material for the full input data). For the QCA, we then used the observed variables to construct ordinal indicators on the strength of each latent construct through simple additive indicators.

For monetary incentives, payments (per hectare) did not differ between farmers. We thus assessed two other observed variables shown to affect perceptions of incentives in PES: from interviews, whether money was a main motivation (J. Fisher, 2012; Martin et al., 2014), and from project documents, whether there were administrative payment delays (unrelated to poor performance) (Cole, 2010; Scullion et al., 2011). For the level of participatory decision making, through interviews and using indicators to similar studies on participation (Bagherian et al., 2011; Izurieta et al., 2011), we assessed observed variables on the extent to which farmers felt able to influence decisions that affected their land: perceptions of whether there were organisational communication issues with the farmer; the presence of personal relationships with project staff; and perceptions of sufficient flexibility in rules. For centralisation, motivated by similar QCAs on governance (Pahl-Wostl \& Knieper, 2014), we used interviews to assess perceptions on the level of top-down control at the village level, and project records to assess the presence of expert staff or consultants in the village. Finally, for decentralisation, we used interviews to generate observed variables on the perceptions of bottom-up collective action-type processes and the number of other participating farmers in the village (Gebremedhin et al., 2004; Meinzen-Dick et al., 2004). We characterised household wealth in each case based upon the previously mentioned wealth ranking exercises in each village. Throughout the interviews, we sought to minimise the risk of reverse causality in variables generated from respondent perceptions (e.g. where respondents' perceptions would be driven by their AGB outcome), by first approach discussing each design feature in a general sense, then asking for their perception now, and if this had changed since they had been monitored or sanctioned.

For water availability, we modelled the mean annual climatic water deficit (CWD) since planting on each farm (see Poorter et al. (2016) for a similar approach). CWD is the 
This is a non-peer reviewed preprint submitted to EarthArXiv and Elsevier.

difference between potential and actual evapotranspiration and provides a more nuanced measure of water availability than simple rainfall indicators. We generated mean annual CWD since planting on each farm using farm location data, spatio-temporal records of temperature and rainfall from Willmot et al. (2014), digital elevation models (INEGI, 2018; USGS, 2006) and the CWD R function from Redmond (2015). We then converted this into an ordinal scale for the QCA.

Finally, to characterise the level of AGB accumulated on each farm, we modelled farm-level AGB using tree growth records for 10 years on each farm (documenting species, tree diameter, tree height and farm area), wood density information and the pantropical allometric model provided by Chave et al. (2009, 2014); and the BIOMASS package in R (RejouMechain et al., 2018). For the purpose of the QCA, we then categorised each farm on a four point ordinal scale, based on quartiles of AGB per hectare across farms (normalised to account for different tree stocking densities).

Table 1. Observed variables used to characerise the different high-level concepts (latent constructs) in our cases. FSSIs = farmer semi-structured interviews; PDs = project documents/records. 
This is a non-peer reviewed preprint submitted to EarthArXiv and Elsevier.

\begin{tabular}{|c|c|c|c|}
\hline Latent construct & Observed variable & Levels and measurement & Source \\
\hline \multirow{2}{*}{$\begin{array}{l}\text { Organisational } \\
\text { œntralisation } \\
\text { (CEN) }\end{array}$} & $\begin{array}{l}\text { Level of centralised project } \\
\text { management in village }\end{array}$ & $\begin{array}{l}\text { High/Low. Respondents reported dose control } \\
\text { at village level. }\end{array}$ & FSSIS \\
\hline & $\begin{array}{l}\text { Level of vertical extension } \\
\text { services in village }\end{array}$ & $\begin{array}{l}\text { High/Low. Presence of a feas bility study } \\
\text { and/or a technician living in the village. }\end{array}$ & PDs \\
\hline \multirow[t]{2}{*}{$\begin{array}{l}\text { Organisational } \\
\text { decentralisation } \\
\text { (DCEN) }\end{array}$} & $\begin{array}{l}\text { Perception of collective acti } \\
\text { on by respondent }\end{array}$ & $\begin{array}{l}\text { Yes/No. Respondent reported a perception of } \\
\text { community responsibility for trees an/or } \\
\text { reported receiving free labour. }\end{array}$ & FSSIS \\
\hline & $\begin{array}{l}\text { Number of other project } \\
\text { participants in the area }\end{array}$ & $\begin{array}{l}\text { Ordinal. Number of other project participants } \\
\text { in the area }\end{array}$ & PDs \\
\hline \multirow{3}{*}{$\begin{array}{l}\text { Level of participat } \\
\text { ion } \\
\text { (PTI) }\end{array}$} & $\begin{array}{l}\text { Communication problems } \\
\text { with project staff }\end{array}$ & $\begin{array}{l}\text { Yes/No. Respondent reported problems in } \\
\text { communication with project intermediary. }\end{array}$ & FSSIS \\
\hline & $\begin{array}{l}\text { Level of flexiblity in land } \\
\text { use permitted by project }\end{array}$ & $\begin{array}{l}\text { High/Low. Respondent reported sufficient } \\
\text { flexiblity in the project }\end{array}$ & FSSIS \\
\hline & $\begin{array}{l}\text { Personal relationship with } p \\
\text { roject forest technician }\end{array}$ & $\begin{array}{l}\text { Yes/No. Respondent reported knowing } \\
\text { technician socially }\end{array}$ & FSSIS \\
\hline \multirow[t]{2}{*}{$\begin{array}{l}\text { Level of monetary } \\
\text { incentives (ITV) }\end{array}$} & $\begin{array}{l}\text { Level of monetary } \\
\text { motivations }\end{array}$ & $\begin{array}{l}\text { Yes/No. Respondent indicated that monetary } \\
\text { benefits were their main motivation }\end{array}$ & FSSIS \\
\hline & Efficiency of payments & $\begin{array}{l}\text { Yes/No. Respondent reported delays in their } \\
\text { payments (that were not related to sanctions) }\end{array}$ & FSSIs \\
\hline $\begin{array}{l}\text { Household } \\
\text { wealth (WLT) }\end{array}$ & $\begin{array}{l}\text { Relative wealth of } \\
\text { household (within village) }\end{array}$ & $\begin{array}{l}\text { Ordinal (from village ranking exercises during } \\
\text { fieldwork) }\end{array}$ & $\begin{array}{l}\text { Ranking } \\
\text { exercise }\end{array}$ \\
\hline $\begin{array}{l}\text { Water availability } \\
\text { (WAT) }\end{array}$ & $\begin{array}{l}\text { Relative water availability } \\
\text { since planting }\end{array}$ & $\begin{array}{l}\text { Generated from plot locations and NOAA } \\
\text { rainfall records }\end{array}$ & $\begin{array}{l}\text { Secondary } \\
\text { data }\end{array}$ \\
\hline $\begin{array}{l}\text { Aboveground } \\
\text { biomass (AGB) }\end{array}$ & $\begin{array}{l}\text { Level of } \\
\text { aboveground biomass on } \\
\text { farm }\end{array}$ & $\begin{array}{l}\text { Ordinal. Level of AGB accumulation relative to } \\
\text { other farmers doing the same type of } \\
\text { agroforestry. }\end{array}$ & PDs \\
\hline
\end{tabular}

\section{Fuzzy set QCA (QCA)}

QCA is a form of qualitative analysis which is useful for finding patterns in datasets with too few cases for robust statistical analyses, but which are too large for common qualitative thematic or narrative syntheses (Jordan et al., 2011). It uses set theory and Boolean algebra (the same logic used in Venn diagrams) to find logical patterns in data where sets of 'causal conditions' lead to a particular 'outcome condition' (Dusa, 2019). QCA is has been used widely in social science, economics and engineering, and is increasingly being used in studies of environmental change (Hudson \& Kuehner, 2013; Rudel et al., 2009). QCA does not make strong generalisable statements about causation (i.e. where a change in factor always changes an outcome variable; Meyfroidt, 2016), but rather implies 'conjectural causation' where, based on a critical assessment of the results, different theories and associated propositions about the causal pathways are supported or not supported in our cases (Jordan et al., 2011). 
In this study we use QCA to initially identify patterns across our cases of the co-occurence of different levels of monetary incentives, participation and (de)centralisation, alongside levels of AGB accumulation. We then explore these in more depth through thematic analysis of interviews, and discuss the implications for PES theory. For our cases, the 'outcome condition' in the QCA is the level of AGB achieved in each case, while everything else is a 'causal condition'. Inputs and outputs of QCA resemble the 'truth table' at Table 2. A truth table groups all cases together based on the pattern of their causal conditions and outcomes (each pattern being a 'complete product'). QCA can then be used to find a 'minimised solution term' which uses Boolean logical minimisation to find across all complete products the simplest common combination of causal conditions for a particular outcome. It does this by comparing all complete products and using logic to eliminate redundant causal conditions (e.g. in its simplest form, if condition $X$ occurs in both positive and negative sets with outcome $Y$, it has no explanatory power and is eliminated). This minimised solution is notionally the 'best' explanation for an outcome.

Following Dusa (2019), we implement fuzzy set QCA which (unlike crisp set QCA) allows a case to be a partial member of different sets at the same time (e.g. instead of rich or poor, a household can be both to different degrees). Following the construction of the ordinal variables for our latent constructs, we calibrated each variable using totally fuzzy and relative (TFR) calibration, which is appropriate for both ordinal and interval variables. TFR uses the existing data to calculate an empirical cumulative distribution function for a variable, then uses rank orders of cases from this function to transform the data into fuzzy membership scores from 0 to 1.

To assess the validity of our findings, we focus on the 'sufficiency' of different causal conditions to explain high AGB outcomes. A condition is sufficient where it is commonly associated with an outcome, as measured by: 'consistency', an indicator of robustness of the causal pattern (i.e. condition $X$ is perfectly consistent and sufficient if every time $X$ occurs it is also with outcome $Y$ ); and 'coverage', the proportion of an outcome explained by the condition (similar to $\mathrm{R}^{2}$ in statistics; i.e. condition $\mathrm{X}$ has perfect coverage if every time outcome $\mathrm{Y}$ occurs it is also with $\mathrm{X}$ ). Values for consistency and coverage are always between 0 and 1, with higher values indicating greater internal validity. We implement a high consistency threshold (i.e. cut-off value) of 0.85 (Rihoux \& Ragin, 2008), above which a case is assigned to that set. We implemented the QCA using the QCA package in R, version 3.5.1 (R Core Team, 2019).

\section{Linking QCA to farmer perspectives and experiences}

After running and assessing the validity of the QCA, we then related the patterns apparent in the results to those individual experiences conveyed in interviews. We did this through a thematic synthesis approach, where we reviewed each interview with the QCA results in mind to gain in depth and contrasting insights on each of design features under consideration (Ritchie et al., 2013). In our results below we include selected quotes from respondents to give a voice to the general themes across the interviews. To further unpack the QCA, and to better understand which underlying observed variables were driving the results, we also examined the QCA outcomes for each case alongside their underlying observed variables (see Table S1 in the Supplementary Material). 
This is a non-peer reviewed preprint submitted to EarthArXiv and Elsevier.

\section{Results}

QCA results

The QCA results are summarised in Table 2, where 15 of our 39 cases were assessed to have high AGB outcomes to a high degree of consistency (consistency $>0.85$ ). These high AGB cases covered sites from both countries. The truth table results show that good AGB outcomes almost always occurred with perceptions of both good participation and good monetary incentives. AGB outcomes were usually poorer where one of these was lacking, with the exception of two cases (cases 9 and 10). These two cases scored well on wealth and water availability, and interviews with the associated farmers suggested that their wealth and environmental context allowed them to 'continue on the path' of supporting their trees despite lower monetary incentives. The degree of (de)centralisation had no clear pattern: all cases, whether with high or low AGb outcomes, had either strong centralised or decentralised structures (or the co-occurrence of both). Wealth and water availability also had no clear pattern.

The logical minimised parsimonious solution term emphasises the importance of participation and incentives in our cases, and of household wealth (Table 2). The minimised term also suggests that, in our cases, high AGB occurred with low organisational centralisation where participation was perceived to be high.

The QCA results can be further unpacked by reviewing the underlying observed variables (Table S1), which show that good AGB outcomes mainly occurred alongside good relationships with project technicians, efficient and high monetary payments, and high horizontal (farmer to farmer) cooperation and extension.

Table 2. Raw truth table and minimised parsimonious solution from the QCA. In the truth table, the level of aboveground biomass (AGB) in the case is the outcome variable, while causal conditions are: degree of organisational centralisation (CEN); degree of organisational decentralisation (DCEN); level of participation in decision making (PTI); perceived level of monetary incentives (ITV); household wealth rank (WLT); and water availability since planting (WAT). A score of 1 means that the case performed strongly on that criteria. In the minimised solution term, * represents the Boolean AND operation, while + means OR. Variables in capitals and lowercase respectively represent high and low scores. 
This is a non-peer reviewed preprint submitted to EarthArXiv and Elsevier.

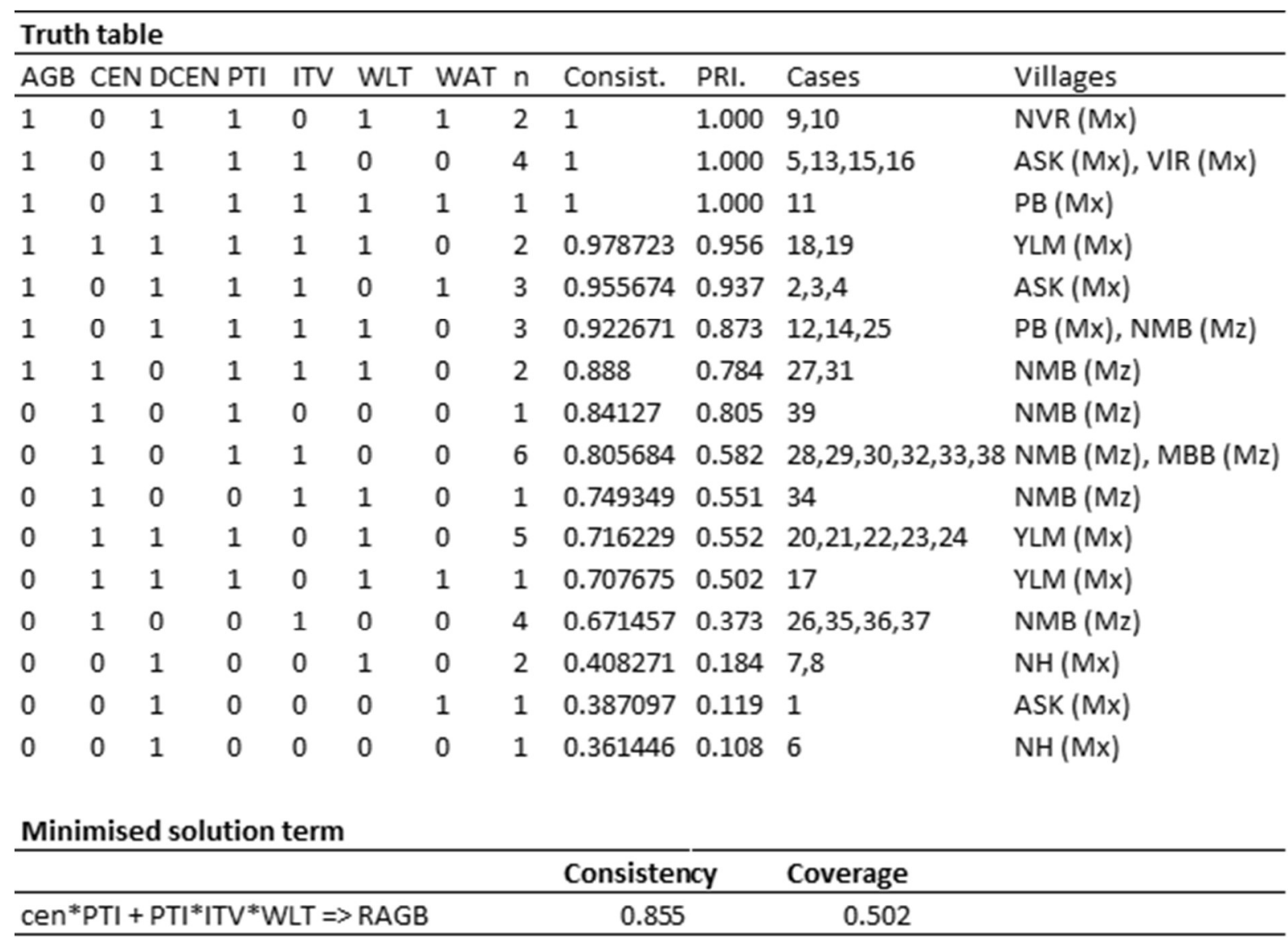

Farmer perspectives and case contexts

Broadly, perspectives from local farmers and technicians accorded with the QCA results that both incentives and participation in decision making were important (Box 1). For incentives, these local perspectives then went further to suggest that, in addition to short term monetary incentives, AGB outcomes were better for farmers who also had prominent non-monetary motivations. For participation in decision making, farmers emphasised the importance of good relations with project technicians.

\section{Box 1. Local perspectives on participation and incentives Importance of monetary incentives \\ “ ... a few people stopped [looking after their saplings] because they didn't get paid on time,} which then caused the trees to be sick."

Farmer, Mexico

"Some farmers lack interest because they don't understand the financial benefits... there is some [short term] benefit now from the fruit trees but they want the money from timber, which takes too long for them."

Farmer, Mozambique

\section{Importance of non-monetary motivations}


This is a non-peer reviewed preprint submitted to EarthArXiv and Elsevier.

"Trees are like children. You need to care for them. Some people stop giving proper care
because they are only interested in the payment, and they don't think about the other benefits."

Farmer, Mozambique

"Some people's trees are better than others because of the soils and shade, but also because some people are better at looking after the trees ... because they find the trees beautiful"

Farmer, Mexico

\section{Importance of technician relations}

"I lived next door to the house where the project technicians would stay. It helped to have them next door. They would always come and give advice which helped the trees."

Farmer, Mozambique

"After the first few years there was a problem with the technician in the village and communication with [the project intermediary] broke down. Many farmers found it difficult because of the lack of advice... some trees died because of this."

Agroforestry technician, Mexico

An additional insight from farmer perspectives was the key role of local social and cultural context in determining what was perceived as 'good participation', and in determining preferences for centralised and decentralised organisational structures. While some farmers endorsed flexibility and decentralisation, others reported that they were not bothered by a lack of flexibility in decision making, nor more decentralised hierarchical structures (Box 2).

\section{Box 2. Local perspectives on flexibility and centralisation}

\section{Endorsements of flexibility and decentralisation}

"I planted what project staff told me to plant for the first two times but a few of the trees were still dying ... so I had an idea to try some different local species and they worked. I checked with the project technician and they said it was ok."

Farmer, Mexico

"There was flexibility ... it was good because people wanted to include some fruit trees or let in their cattle ... initially it was not allowed so people were disappointed and unmotivated, but the project agreed after we talked to them."

Farmer, Mexico

\section{Endorsements of centralisation}

"[The project staff] told us what to do, but that was ok. ... I didn't want to experiment in case it went wrong. It was something new and you shouldn't experiment when you don't know what you're doing"

Farmer, Mozambique

"[the village technician] is also a good community leader, so he takes the main decisions about the project ... and we follow him. He organises the farmers."

Farmer, Mexico

There were consultations [by senior project staff] with community leaders, but not with other farmers, and not on the tree species ... they figured out which trees would work then told us. This was good because we didn't know what we were doing and were fearful ... the rules were rigid but it worked because there was a lot to change. People had to stop burning and opening up new farms so rules were necessary 
These different perspectives on flexibility and organisational centralisation appeared linked to the existing practices and expectations of farmers, stemming from their surrounding social, cultural and historical context. In Mexico, the villages of Alan-Samariakantajal (ASK) and Villa las Rosas (VIR) both had an established history of decentralised natural resource management in their villages, and this appears to have led to a preference for decentralised approaches in the agroforestry project. Farmers in the project in Nhambita (Mozambique) on the other hand appeared largely satisfied with a more centralised structure, and this aligns with the existing hierarchical governance at the village-level in the area. The village of Yaluma is unique amongst our cases, with both centralised and decentralised structures appearing to co-exist in the village. Here the village leadership was already highly centralised, but also apparently highly consultative and focused on building consensus and cooperation between participating farmers. This appears to have sparked the development of horizontal structures and cooperation between farmers:

At first the community didn't want to plant the trees but [the village leaders] decided it was good because trees were disappearing from the fields ... so they organised everyone into groups and they began to learn ... people joining later then found it easier because there were lots of educated people to help them.

Farmer, Mexico

Broadly, local perspectives combined to suggest that the shape of the organisational processes, and the nature of participation in decision making, was contingent on sociocultural factors.

\section{Discussion}

Our results emphasise the importance in our cases of both monetary incentives and good participation in decision making. Additionally, our results indicate that the type of participation in our cases, and the effectiveness of different types of (de)centralisation appeared dependent on existing social, cultural and historical context. Given the similarities between our study sites and other smallholder PES programmes, here we argue that our findings have relevance for two key ongoing debates in the PES field.

First, our study speaks directly to the ongoing debate around whether PES projects should prioritise theoretical, economistic concerns around monetary incentives, or the building of local support through flexibility and participatory processes (Ezzine-de-Blas et al., 2016; Pascual et al., 2014; Shapiro-Garza et al., 2020; Wunder et al., 2018). Our findings provide new evidence that there may be no trade-off to be had between these different aspects. In our cases, both considerations had to be satisfied for successful outcomes to occur at the farm level. We view that this is likely a wider phenomenon, and argue that PES projects need to focus on achieving this balance in their project designs, rather than prioritising one over the other.

In addition to informing PES design, we argue that this findings has additional relevance to the adoption of new technologies in PES and associated aims of 'upscaling' (i.e. large scale implementation) PES. Recently, many PES practitioners and theorists have expressed increased interest in using remote sensing, blockchain and cloud-based technologies to reduce transaction costs, improve accountability and upscale PES programmes (Howson et al., 2019; Marke, 2018). On their own, many of the suggested new technologies imply a 
reduced presence in the field which would likely diminish communication with, and representation of, local participants. Should this come to occur, our findings suggest that project outcomes may suffer, and anticipated improvements to cost effectiveness may not occur. While more efficient technologies may assist PES administration, our evidence suggests that any benefits would need to be considered alongside the costs of reduced participation amongst local actors. We argue that any proposed innovations that reduce personal contact with local participants must be paired with strong participatory mechanisms that build and maintain local participation and support.

The second key PES debate to which our findings contribute is the emerging 'best practice' literature for designing PES schemes. There are an increasing number of empirical studies and reviews which attempt to define the key features required for 'successful' PES schemes, ranging from those focused on economic design principles around delivering conditional financial incentives (Börner et al., 2017; Grima et al., 2016; Sattler \& Matzdorf, 2013), to those which have a similar level of focus on additional social and biophysical factors (Bennett \& Gosnell, 2015; Huber-Stearns et al., 2017; Paudyal et al., 2018). While aspects of all of these frameworks are no doubt relevant in different contexts, our study provides new evidence in support of theories that PES and other natural resource management institutions are likely to evolve alongside existing practices and norms rather than being wholly 'designed' by project practitioners (He, 2020; Shapiro-Garza et al., 2020; Van Hecken et al., 2015).

Our cases show the evolution of different organisational processes, even within the same project, and suggest that the path of this evolution was determined by the local socio-cultural context and existing institutions. This finding links to the wider concept of institutional bricolage in natural resource management, and associated theories of critical institutionalism, where the shape of institutions are argued to be the product of continually evolving socio-cultural processes and the agency of individuals (Cleaver \& De Koning, 2015; de Koning et al., 2014; De Koning \& Benneker, 2012). Broadly, we argue that PES programmes should not expect to exert too much direct control over the shape of institutions at the local level. Instead projects should provide flexibility and resources to support a process of institutional adaptation, where institutional processes evolve alongside local norms, needs and expectations.

Relatedly, in contrast to the trend in natural resource management towards more decentralised approaches (which are assumed to be better for, and more widely supported by, local people; Kolinjivadi et al., 2014; Larson \& Soto, 2008) we find that preferences for (de)centralisation vary between participants depending on the local context. There are separate and compelling arguments on the longer term benefits of decentralised institutions for broader sustainable development (and many of these may apply to PES in the long term) (Ribot \& Larson, 2004). However, for PES in the timeframe that we examined here (ten years since planting), it appears that centralised approaches can be just as effective when they are also perceived as legitimate locally.

Similarly, our study contains cases from a village (Yaluma in Mexico) where both strong centralised and decentralised processes successfully occur alongside each other. This provides empirical evidence in support of existing theories that there is not necessarily a dichotomy between centralised and decentralised two approaches in PES: they can co-exist 
in a hybrid or interacting form (e.g. hybrid or nested approaches) (Muradian et al., 2010; Shapiro-Garza et al., 2020) . The question therefore is not 'which side of the centralisation spectrum is best?', but 'what institutional mix is locally appropriate?'. Generally, with regard to best-practice guidelines on PES design, we argue that PES practitioners should be wary of letting strict rules and 'best practice' guidelines hinder the process of local institutional bricolage necessary for a successful scheme - institutions that evolve locally are likely to be more effective than those that are imposed.

One limitation of explicitly aligning PES project process with existing institutions is that, while this may be good for existing land holders and project outcomes, it may limit the transformative potential of PES: building PES on existing structures can simply reinforce existing power imbalances and structural inequalities that may be the root cause of many local social and environmental problems (Baynes et al., 2019; Esteve Corbera et al., 2020; Mahanty et al., 2013; vonHedemann, 2020). Thus, programmes will need to be critical about which existing institutions to engage with and how they do so. Where PES programmes do choose to sponsor radical change and innovation in natural resource management institutions, building local ownership and legitimacy of the process will be key-including by considering how to work constructively with existing institutions, and to be sensitive to the historical, cultural and social context.

\section{Conclusion}

In this study we have used case comparisons across 39 smallholdings in two countries to examine how selected PES design features are linked to actual land management outcomes at the farm-level. Given the typical nature of our cases, we argue that our findings provide new insights relevant to the wider PES field. Our cases show that the delivery of monetary incentives and participatory mechanisms are likely equally important in supporting successful outcomes. Additionally, our evidence shows that institutional arrangements at the local level are likely to evolve with the local context rather than being explicitly designed or imposed.

Our findings suggest that attempts to improve the performance of PES schemes by enshrining 'best practice' or key design principles must put equal emphasis on economistic design principles and the maintenance of local legitimacy, and should be flexible enough to allow for local processes of institutional bricolage. Further, the introduction of new technologies and other reforms to PES practice must maintain strong participatory mechanisms at the local level--payments and technology will likely be insufficient substitutes for participation and people.

\section{References}

Bagherian, R., Goodarzi, M. M., \& Shadfar, S. (2011). Relationship between attitude toward watershed management programs and level of participation. Middle-East Journal of Scientific Research, 9(3), 324-329.

Bainbridge, V. (2000). Transforming bureaucracies: Institutionalising participation and people centred processes in natural resource management: An annotated bibliography. 
This is a non-peer reviewed preprint submitted to EarthArXiv and Elsevier.

International Institute for Environment and Development (IIED).

Baynes, J., Herbohn, J., Gregorio, N., Unsworth, W., \& Tremblay, É. H. (2019). Equity for Women and Marginalized Groups in Patriarchal Societies during Forest Landscape Restoration: The Controlling Influence of Tradition and Culture. Environmental Conservation, 46(3), 241-246.

Bennett, D. E., \& Gosnell, H. (2015). Integrating multiple perspectives on payments for ecosystem services through a social-ecological systems framework. Ecological Economics, 116, 172-181.

Blaikie, P. (2006). Is small really beautiful? Community-based natural resource management in Malawi and Botswana. World Development, 34(11), 1942-1957.

Blomquist, W., Dinar, A., \& Kemper, K. E. (2010). A framework for institutional analysis of decentralization reforms in natural resource management. Society and Natural Resources, 23(7), 620-635.

Börner, J., Baylis, K., Corbera, E., Ezzine-de-Blas, D., Ferraro, P. J., Honey-Rosés, J., Lapeyre, R., Persson, U. M., \& Wunder, S. (2016). Emerging evidence on the effectiveness of tropical forest conservation. PloS One, 11(11).

Börner, J., Baylis, K., Corbera, E., Ezzine-de-Blas, D., Honey-Rosés, J., Persson, U. M., \& Wunder, S. (2017). The effectiveness of payments for environmental services. World Development, 96, 359-374.

Bryan, B. A. (2013). Incentives, land use, and ecosystem services: Synthesizing complex linkages. Environmental Science \& Policy, 27, 124-134.

Chervier, C., Velly, G. L., \& Ezzine-de-Blas, D. (2017). When the Implementation of Payments for Biodiversity Conservation Leads to Motivation Crowding-out: A Case Study From the Cardamoms Forests, Cambodia. Ecological Economics. https://doi.org/10.1016/j.ecolecon.2017.03.018

Cleaver, F. (2017). Development through bricolage: Rethinking institutions for natural resource management. Routledge.

Cleaver, F., \& De Koning, J. (2015). Furthering critical institutionalism. International Journal 
This is a non-peer reviewed preprint submitted to EarthArXiv and Elsevier.

of the Commons, 9(1), 1-18.

Cole, R. J. (2010). Social and environmental impacts of payments for environmental services for agroforestry on small-scale farms in southern Costa Rica. International Journal of Sustainable Development \& World Ecology, 17(3), 208-216.

Corbera, E., Kosoy, N., \& Tuna, M. M. (2007). Equity implications of marketing ecosystem services in protected areas and rural communities: Case studies from Meso-America. Global Environmental Change-Human and Policy Dimensions, 17(3-4), 365-380. https://doi.org/10.1016/j.gloenvcha.2006.12.005

Corbera, Esteve, \& Brown, K. (2008). Building Institutions to Trade Ecosystem Services: Marketing Forest Carbon in Mexico. World Development, 36(10), 1956-1979. https://doi.org/10.1016/j.worlddev.2007.09.010

Corbera, Esteve, Costedoat, S., Ezzine-de-Blas, D., \& Van Hecken, G. (2020). Troubled Encounters: Payments for Ecosystem Services in Chiapas, Mexico. Development and Change, 51(1), 167-195. https://doi.org/10.1111/dech.12540

Corbera, Esteve, Soberanis, C. G., \& Brown, K. (2009). Institutional dimensions of Payments for Ecosystem Services: An analysis of Mexico's carbon forestry programme.

Ecological Economics, 68(3), 743-761.

https://doi.org/10.1016/j.ecolecon.2008.06.008

De Koning, J., \& Benneker, C. (2012). Bricolage practices in local forestry. In Forest and Nature Governance (pp. 49-67). Springer.

de Koning, J., Turnhout, E., Winkel, G., Blondet, M., Borras, L., Ferranti, F., Geitzenauer, M., Sotirov, M., \& Jump, A. (2014). Managing climate change in conservation practice: An exploration of the science-management interface in beech forest management. Biodivers Conserv, 23(14), 3657-3671. https://doi.org/10.1007/s10531-014-0781-8

Dusa, A. (2019). QCA with R. A Comprehensive Resource. Springer International Publishing.

Engel, S., Pagiola, S., \& Wunder, S. (2008). Designing payments for environmental services in theory and practice: An overview of the issues. Ecological Economics, 65(4), 663- 
This is a non-peer reviewed preprint submitted to EarthArXiv and Elsevier.

674. https://doi.org/10.1016/j.ecolecon.2008.03.011

Escobar, M. M., Hollaender, R., \& Weffer, C. P. (2013). Institutional durability of payments for watershed ecosystem services: Lessons from two case studies from Colombia and Germany. Ecosystem Services, 6, 46-53.

Ezzine-de-Blas, D., Corbera, E., \& Lapeyre, R. (2019). Payments for environmental services and motivation crowding: Towards a conceptual framework. Ecological Economics, $156,434-443$.

Ezzine-de-Blas, D., Wunder, S., Ruiz-Pérez, M., \& del Pilar Moreno-Sanchez, R. (2016). Global patterns in the implementation of payments for environmental services. PloS One, 11(3).

Ferraro, P. J., \& Kiss, A. (2002). Ecology. Direct payments to conserve biodiversity. Science, 298(5599), 1718-9. https://doi.org/10.1126/science.1078104

Ferraro, Paul J. (2001). Global Habitat Protection: Limitations of Development Interventions and a Role for Conservation Performance Payments. Conservation Biology, 15(4), 990-1000. https://doi.org/10.1046/j.1523-1739.2001.015004990.x

Fisher, J. (2012). No pay, no care? A case study exploring motivations for participation in payments for ecosystem services in Uganda. Oryx, 46(01), 45-54. https://doi.org/10.1017/s0030605311001384

Fisher, J. A., Cavanagh, C. J., Sikor, T., \& Mwayafu, D. (2018). Linking notions of justice and project outcomes in carbon offset forestry projects: Insights from a comparative study in Uganda. Land Use Policy, 73, 259-268.

Fowler, A. (1992). Decentralisation for international NGOs. Development in Practice, 2(2), $121-124$.

Fowler, A. (2000). Degrees of separation: Perspectives on the decentralisation of international NGOs'. S. Gibbs, 'Decentralised NGO Management', Occasional Paper, 19, 8-24.

Gebremedhin, B., Pender, J., \& Tesfay, G. (2004). Collective action for grazing land management in crop-livestock mixed systems in the highlands of northern Ethiopia. 
This is a non-peer reviewed preprint submitted to EarthArXiv and Elsevier.

Agricultural Systems, 82(3), 273-290.

Gibbs, S., Smillie, I., Pratt, B., \& Fowler, A. (2000). Decentralised NGO Management. INTRAC.

Grima, N., Singh, S. J., Smetschka, B., \& Ringhofer, L. (2016). Payment for Ecosystem Services (PES) in Latin America: Analysing the performance of 40 case studies. Ecosystem Services, 17, 24-32.

Gross-Camp, N. D., Martin, A., McGuire, S., Kebede, B., \& Munyarukaza, J. (2012). Payments for ecosystem services in an African protected area: Exploring issues of legitimacy, fairness, equity and effectiveness. Oryx, 46(01), 24-33. https://doi.org/10.1017/s0030605311001372

He, J. (2020). Situated Payments for Ecosystem Services: Local Agencies in the Implementation of the Sloping Land Conversion Programme in Southwest China. Development and Change, 51(1), 73-93. https://doi.org/10.1111/dech.12539

Hegde, R., Bull, G. Q., Wunder, S., \& Kozak, R. A. (2015). Household participation in a payments for environmental services programme: The Nhambita Forest Carbon Project (Mozambique). Environment and Development Economics, 20(5), 611-629.

Howson, P., Oakes, S., Baynham-Herd, Z., \& Swords, J. (2019). Cryptocarbon: The promises and pitfalls of forest protection on a blockchain. Geoforum, 100, 1-9.

Huber-Stearns, H. R., Bennett, D. E., Posner, S., Richards, R. C., Fair, J. H., Cousins, S. J., \& Romulo, C. L. (2017). Social-ecological enabling conditions for payments for ecosystem services. Ecology and Society, 22(1).

Hudson, J., \& Kuehner, S. (2013). Qualitative comparative analysis and applied public policy analysis: New applications of innovative methods. Policy and Society, 32(4), 279287.

Izurieta, A., Sithole, B., Stacey, N. E., Hunter-Xenie, H. M., Campbell, B. M., Donohoe, P., Brown, J., \& Wilson, L. (2011). Developing indicators for monitoring and evaluating joint management effectiveness in protected areas in the Northern Territory, Australia. Ecology and Society, 16(3). 
This is a non-peer reviewed preprint submitted to EarthArXiv and Elsevier.

Jordan, E., Gross, M. E., Javernick-Will, A. N., \& Garvin, M. J. (2011). Use and misuse of qualitative comparative analysis. Construction Management and Economics, 29(11), $1159-1173$.

Kerr, J., Vardhan, M., \& Jindal, R. (2012). Prosocial behavior and incentives: Evidence from field experiments in rural Mexico and Tanzania. Ecological Economics, 73, 220-227.

Kolinjivadi, V., Adamowski, J., \& Kosoy, N. (2014). Recasting payments for ecosystem services (PES) in water resource management: A novel institutional approach. Ecosystem Services, 10, 144-154.

Lansing, D. M. (2017). Understanding smallholder participation in payments for ecosystem services: The case of Costa Rica. Human Ecology, 45(1), 77-87.

Larson, A. M., \& Soto, F. (2008). Decentralization of natural resource governance regimes. Annual Review of Environment and Resources, 33, 213-239.

Leach, M., Bloom, G., Ely, A., Nightingale, P., Scoones, I., Shah, E., \& Smith, A. (2007). Understanding governance: Pathways to sustainability. STEPS Centre, Institute of Development Studies.

Lockwood, M., Davidson, J., Curtis, A., Stratford, E., \& Griffith, R. (2010). Governance principles for natural resource management. Society and Natural Resources, 23(10), 986-1001.

Lowndes, V., \& Roberts, M. (2013). Why institutions matter: The new institutionalism in political science. Macmillan International Higher Education.

Madon, S. (1999). International NGOs: Networking, information flows and learning. The Journal of Strategic Information Systems, 8(3), 251-261.

Mahanty, S., Suich, H., \& Tacconi, L. (2013). Access and benefits in payments for environmental services and implications for REDD+: Lessons from seven PES schemes. Land Use Policy, 31, 38-47.

Marke, A. (2018). Transforming Climate Finance and Green Investment with Blockchains. Academic Press.

Martin, A., Gross-Camp, N., Kebede, B., \& McGuire, S. (2014). Measuring effectiveness, 
This is a non-peer reviewed preprint submitted to EarthArXiv and Elsevier.

efficiency and equity in an experimental Payments for Ecosystem Services trial. Global Environmental Change, 28, 216-226.

https://doi.org/10.1016/j.gloenvcha.2014.07.003

Meinzen-Dick, R., DiGregorio, M., \& McCarthy, N. (2004). Methods for studying collective action in rural development. Agricultural Systems, 82(3), 197-214.

Meyfroidt, P. (2016). Approaches and terminology for causal analysis in land systems science. Journal of Land Use Science, 11(5), 501-522.

Muradian, R., Corbera, E., Pascual, U., Kosoy, N., \& May, P. H. (2010). Reconciling theory and practice: An alternative conceptual framework for understanding payments for environmental services. Ecological Economics, 69(6), 1202-1208.

Nieratkaa, L. R., Bray, D. B., \& Mozumder, P. (2015). Can Payments for Environmental Services Strengthen Social Capital, Encourage Distributional Equity, and Reduce Poverty? Conservation and Society, 13(4), 345. https://doi.org/10.4103/09724923.179880

OPHI. (2015). Global MPI Country Briefing: Mexico, 2015. In Multidimensional Poverty Index Data Bank. OPHI, University of Oxford.

OPHI. (2018). Global MPI Country Briefing: Mozambique, 2018. In Multidimensional Poverty Index Data Bank. OPHI, University of Oxford.

Pahl-Wostl, C., \& Knieper, C. (2014). The capacity of water governance to deal with the climate change adaptation challenge: Using fuzzy set Qualitative Comparative Analysis to distinguish between polycentric, fragmented and centralized regimes. Global Environmental Change, 29, 139-154.

Pascual, U., Phelps, J., Garmendia, E., Brown, K., Corbera, E., Martin, A., GomezBaggethun, E., \& Muradian, R. (2014). Social Equity Matters in Payments for Ecosystem Services. BioScience, 64(11), 1027-1036. https://doi.org/10.1093/biosci/biu146

Paudyal, K., Baral, H., Bhandari, S. P., \& Keenan, R. J. (2018). Design considerations in supporting payments for ecosystem services from community-managed forests in 
This is a non-peer reviewed preprint submitted to EarthArXiv and Elsevier.

Nepal. Ecosystem Services, 30, 61-72.

Peckham, S., Exworthy, M., Powell, M., \& Greener, I. (2005). Decentralisation, centralisation and devolution in publicly funded health services: Decentralisation as an organisational model for health-care in England. London School of Hygiene \& Tropical Medicine.

Ribot, J. C., \& Larson, A. M. (2004). Democratic decentralisation through a natural resource lens: Cases from Africa, Asia and Latin America. Routledge.

Rihoux, B., \& Ragin, C. C. (2008). Configurational comparative methods: Qualitative comparative analysis (QCA) and related techniques (Vol. 51). Sage Publications.

Ritchie, J., Lewis, J., Nicholls, C. M., Ormston, R., \& others. (2013). Qualitative research practice: A guide for social science students and researchers. Sage Publications.

Rudel, T. K., Defries, R., Asner, G. P., \& Laurance, W. F. (2009). Changing drivers of deforestation and new opportunities for conservation. Conservation Biology, 23(6), $1396-1405$.

Ruiz-De-Oña-Plaza, C., Soto-Pinto, L., Paladino, S., Morales, F., \& Esquivel, E. (2011). Constructing public policy in a participatory manner: From local carbon sequestration projects to network governance in Chiapas, Mexico. In Carbon Sequestration Potential of Agroforestry Systems (pp. 247-262). Springer.

Sattler, C., \& Matzdorf, B. (2013). PES in a nutshell: From definitions and origins to PES in practice-Approaches, design process and innovative aspects. Ecosystem Services, 6, 2-11.

Scullion, J., Thomas, C. W., Vogt, K. A., PÉRez-Maqueo, O., \& Logsdon, M. G. (2011). Evaluating the environmental impact of payments for ecosystem services in Coatepec (Mexico) using remote sensing and on-site interviews. Environmental Conservation, 38(04), 426-434. https://doi.org/10.1017/s037689291100052x

Shapiro-Garza, E., McElwee, P., Van Hecken, G., \& Corbera, E. (2020). Beyond Market Logics: Payments for Ecosystem Services as Alternative Development Practices in the Global South. Development and Change, 51(1), 3-25. 
This is a non-peer reviewed preprint submitted to EarthArXiv and Elsevier.

https://doi.org/10.1111/dech.12546

Singh, N. M. (2015). Payments for ecosystem services and the gift paradigm: Sharing the burden and joy of environmental care. Ecological Economics, 117, 53-61.

Van Hecken, G., Bastiaensen, J., \& Windey, C. (2015). Towards a power-sensitive and socially-informed analysis of payments for ecosystem services (PES): Addressing the gaps in the current debate. Ecological Economics, 120, 117-125.

Vatn, A. (2010). An institutional analysis of payments for environmental services. Ecological Economics, 69(6), 1245-1252.

vonHedemann, N. (2020). Transitions in Payments for Ecosystem Services in Guatemala:

Embedding Forestry Incentives into Rural Development Value Systems.

Development and Change, 51(1), 117-143. https://doi.org/10.1111/dech.12547

Wunder, S., Brouwer, R., Engel, S., Ezzine-de-Blas, D., Muradian, R., Pascual, U., \& Pinto, R. (2018). From principles to practice in paying for nature's services. Nature Sustainability, 1(3).

Yin, R. K. (2014). Case study research: Design and methods. Los Angeles. 